\title{
Irradiance Levels Affect in vitro and Greenhouse Growth, Flowering, and Photosynthetic Behavior of A Hybrid Phalaenopsis Orchid
}

\author{
Elise A. Konow ${ }^{1}$ and Yin-Tung Wang ${ }^{2}$ \\ Department of Horticultural Sciences, Texas A\&M University System Agricultural Research and \\ Extension Center, 2415 East Highway 83, Weslaco, TX 78596-8399
}

ADDITIONAL INDEX WORDS. moth orchid, potted flowering plants, floriculture, lighting, carbohydrate, malic acid

\begin{abstract}
Presently, there are no standards for producing Phalaenopsis Blume (the moth orchids) as a flowering, potted crop. Determining optimal irradiance for in vitro and greenhouse production will help optimize growth and flowering. Fourmonth-old, aseptically propagated Phalaenopsis Atien Kaala seedlings with $1.0 \mathrm{~cm}$ leaf spread were transferred to a sterile agar medium in November 1995. They were placed under $10,20,40$, or $80 \mu \mathrm{mol} \cdot \mathrm{m}^{-2} \cdot \mathrm{s}^{-1}$ photosynthetic photon flux $(P P F)$ from cool-white fluorescent lamps. In June 1996, plants grown under 40 or $80 \mu \mathrm{mol} \cdot \mathrm{m}^{-2} \cdot \mathrm{s}^{-1}$ in vitro $P P F$ had $38 \%$ greater fresh weight (FW), wider leaves, and more roots than those under the two lower PPF levels. Plants from each in vitro $P P F$ were then transplanted and grown ex vitro in a greenhouse $(\mathrm{GH})$ under high, medium, or low $P P F$, representing $12.0 \%, 5.4 \%$, or $2.6 \%$ of full sunlight, respectively. Full sunlight at this location was 2300 and $1700 \mu \mathrm{mol}^{\circ} \mathrm{m}^{-2} \cdot \mathrm{s}^{-1}$ in August 1996 and January 1997, respectively. In November 1996 and June 1997, plants that had received $40 \mu \mathrm{mol} \cdot \mathrm{m}^{-2} \cdot \mathrm{s}^{-1}$ in vitro $P P F$ and then grown under the high or medium GH PPF had the greatest FWs. Overall, plants under the high, medium, or low GH PPF had average FWs of 61, 36, or $17 \mathrm{~g}$, respectively, in June 1997. By mid-September 1997, plants had increasingly larger leaves and higher concentrations of malic acid, sucrose, and starch as GH PPF increased. Leaf glucose and fructose concentrations remained constant as GH PPF increased; however, sucrose level doubled and malic acid concentration increased by nearly $50 \%$ from the low to high GH PPF. Each doubling in GH PPF more than doubled plant FW. Plants grown under the high, medium, or low GH PPF had $98 \%$, 77\%, or $2 \%$ flowering, respectively, in Spring 1998. Anthesis occurred 2 weeks earlier under the high GH PPF. Plants grown under the high GH PPF had twice as many flowers and larger flowers than those grown under the medium PPF.
\end{abstract}

Dramatic increases in the popularity of Phalaenopsis (the moth orchids) as pot plants worldwide is the result of a combination of factors including creation of new hybrids, relatively short juvenile periods, ease in production, tolerance to low light levels, and extremely long-lasting flowers (Wang, 1998). The value and production of potted, blooming orchids have been increasing in the United States. In 1996, 8.6 million pots of orchids were sold as potted flowering plants (U.S. Department Agriculture (USDA), 1997). The wholesale value of potted orchids totaled $\$ 79$ million in 1999 (USDA, 2000), an increase of $22 \%$ over 1998, the majority being Phalaenopsis orchids. In 1993, auction sales of potted Phalaenopsis orchids alone in Japan totaled \$103 million (U.S. dollars) (Hew and Yong, 1997). Similar success with Phalaenopsis orchids in the United States may be possible with more knowledge about this genus leading to improvements in production techniques and reduced costs.

The genus Phalaenopsis comprises $\approx 54$ species (Fanfani and Rossi, 1988) and hybrids have been created using every Phalaenopsis sp. identified (Griesbach, 1995). However, research for developing standard commercial production techniques is still needed. The disadvantage of producing orchids, including Phalaenopsis, is the extended time required to produce a flowering potted plant from seed. Since orchid seeds have only an embryo and no significant amount of reserve nutrients, they must be sown on a sterile culture medium and remain under such conditions for up to 1 year. Plantlets are then transferred to seedling flats or small thumb pots (Hew and Yong, 1997). When

Received for publication 17 Aug. 2000. Accepted for publication 30 Apr. 2001 The cost of publishing this paper was defrayed in part by the payment of page charges. Under postal regulations, this paper therefore must be hereby marked advertisement solely to indicate this fact.

${ }^{1}$ Former graduate research assistant.

${ }^{2}$ Professor of Floriculture and corresponding author; e-mail: yt-wang@ tamu.edu. of sufficient size, they are transferred periodically to larger pots. Plants may be sold at each stage as unfinished plants, or may be transferred to $15-\mathrm{cm}$ (1.5 to 1.75-L) or larger pots and sold in bud or as flowering plants. The entire process often takes as long as three or more years, depending upon the hybrid and growing technique.

An important factor influencing variability in production time is the irradiance provided during production. Flasks are often stacked on top of each other in culture rooms to maximize space usage, resulting in uneven light disbursement in the vessels and large variations in plant growth. Alternatively, some growers place flasks directly in the greenhouse in an effort to provide higher irradiance and possibly accelerate in vitro growth.

Research by Kajihara (1993) in Hiroshima, Japan, demonstrated a close relationship between initial plant size at deflasking and later growth and flowering. Economou and Read (1987) noted that light influenced subsequent growth of in vitro cultures both directly and indirectly. Cymbidium georingii (Reichb.f.) Reichb.f., a terrestrial orchid, produced more adventitious roots in response to increasing irradiance as opposed to various light qualities (Ueda and Torikata, 1972). Higher irradiance may reduce the time that plantlets of Phalaenopsis orchids have to remain in vitro by promoting growth and development, resulting in larger plants and shorter production time.

Emergence of flowering stems in Phalaenopsis is triggered by air temperature between 25 and $15{ }^{\circ} \mathrm{C}$ for 4 to 5 weeks (Lee, 1990). Recent research has discovered that proper lighting is also essential for triggering flowering stem emergence while plants are being exposed to cool air (Wang, 1995, 1997). Interactions between temperature and light could be used to manipulate the time of inflorescence development (Wang, 1998).

The following study was conducted to determine the effect of irradiance on Phalaenopsis seedling growth in vitro. Effects of 
various levels of irradiance in a greenhouse on ex vitro growth and flowering, as well as the products of photosynthesis were also investigated.

\section{Materials and Methods}

IN VITRO PHASE. Seeds from selfing the TSC 22 clone of a hybrid Phalaenopsis Atien Kaala were sown aseptically 21 July 1995. Seedlings with a leaf spread of $1 \mathrm{~cm}$ were selected and transferred to a sterile agar orchid culture medium in $10 \times 10 \mathrm{~cm}$ polycarbonate boxes (Zuma Canyon Orchids, Malibu, Calif.), 25 plants per box. Treatments began 24 Nov. 1995, in a culture room maintained at $27 \pm 1{ }^{\circ} \mathrm{C}$ with a 12 -h photoperiod. Cool-white fluorescent lighting was used to obtain photosynthetic photon flux $(P P F)$ levels of $10,20,40$, or $80 \mu \mathrm{mol} \cdot \mathrm{m}^{-2} \cdot \mathrm{s}^{-1} . P P F$ was measured at plant level with a LI-2300 meter equipped with a LI189S quantum sensor (LI-COR, Lincoln, Nebr.). Five boxes were placed under each of the four $P P F$ treatments. Plants remained under these treatments until they reached a sufficient size to be transferred to seedling flats.

Seedlings were removed from in vitro treatments between 19 and 23 June 1996. The 18 largest plants were removed from each of the five boxes under each in vitro $P P F$. Leaf number, length and width of the largest leaf, primary root number and length, and total fresh weight (FW) were recorded for each of these plants.

GREENHOUSE PHASE. The 90 plantlets from each of the four in vitro treatments were divided into three groups of 30 plants each. These seedlings were planted in 73-cell (35-mL-volume) seedling flats. Sphagnum moss was used as the growing medium.

The four rows of plants in every flat, each with five plantlets from a different in vitro $P P F$, were arranged in a randomized complete block design that represented one of six replications. These flats were placed in a greenhouse (covered with two layers of polyethylene film and a 73\% shade polypropylene material) under one of three chambers $(120 \mathrm{~cm}$ long, $120 \mathrm{~cm}$ wide, and 75 $\mathrm{cm}$ tall). These chambers were covered with polypropylene shade cloth to provide high, medium, or low $P P F$, representing $12 \%$, $5.4 \%$, or $2.6 \%$ of full sunlight. These oversized shade chambers were needed to avoid the extra shading caused by the sides during early morning and late afternoon. The $P P F$ levels were measured at irregular intervals throughout the course of the experiment within chambers (Fig. 1). Full sunlight at this location (lat. $26.15^{\circ} \mathrm{N}$ ) was 2300 and 1700 $\mu \mathrm{mol} \cdot \mathrm{m}^{-2} \cdot \mathrm{s}^{-1}$ in August 1996 and January 1997, respectively.

On 29 Nov. 1996, the 24 largest seedlings out of 30 were selected from each of the previous four in vitro $P P F$ treatments per GH $P P F$ and transplanted to $0.55-\mathrm{L}$ round $(11.4-\mathrm{cm}-$ diameter) pots. The potting medium contained by volume $7 \%$ sphagnum peat, $16.5 \%$ fine hardwood charcoal, $16.5 \%$ commercial peatbased medium (Sunshine Mix \#1, Sun Gro Horticulture, Inc., Bellevue, Wash.), 27\% fine Douglas fir [Pseudotsuga menziesii (Mirb.) Franco] bark, and 33\% medium grade (4 to 16 $\mathrm{mm}$ particle size) perlite. A complete micronutrient formulation (Micromax, Grace-Sierra, Milipitas, Calif.) at a rate of $0.5 \mathrm{~g} \cdot \mathrm{L}^{-1}$ and powdered dolomite limestone at a rate of $3 \mathrm{~g} \cdot \mathrm{L}^{-}$ ${ }^{1}$ were added to the medium. Plants were placed back in their respective greenhouse light treat- ments following transplanting. One plant per pot represented an experimental unit, with 24 replications per treatment.

Due to the increased leaf size and root growth, plants had to be transplanted into $1.75-\mathrm{L}$ (15.2-cm-diameter, 14-cm-tall) pots on 29 June 1997. The medium consisted of equal volumes of medium size perlite, medium size charcoal, fine Douglas fir bark, and Canadian sphagnum peat. Micromax and powdered dolomite were added at the same rates as the previous planting. Whole plant FW was recorded at each transplanting.

On 15 Sept. 1997, growth data including leaf length, width, and thickness of the youngest mature leaf were collected on all 24 replications. Shoot and root FWs, leaf number, and total leaf area were recorded on 11 randomly selected replications. Leaf area was measured with a leaf area meter.

MaliC ACID. Phalaenopsis orchids exhibit the crassulacean acid metabolism (CAM) photosynthetic pathway (Kubota et al., 1997). Leaf samples of four randomly selected replications were harvested between 0400 and 0540 HR on 29 Sept. 1997 for determining malic acid concentration (Kubota et al., 1997). The youngest mature leaf on each selected plant was removed in the dark, weighed, and area recorded. The leaves were then killed by immersion in liquid nitrogen and stored at $-40{ }^{\circ} \mathrm{C}$ until analyses could be conducted a few days later. The leaf blade was ground while still frozen. The homogenate was strained with a nylon fabric having $200-\mu \mathrm{m}$ openings, mixed with $2 \%$ (by weight) powdered activated charcoal, and filtered. The filtrate was first passed through a $5-\mu \mathrm{m}$ prefilter and subsequently through a 0.45 $\mu \mathrm{m}$ cellulose nitrate membrane filter (Advantec MFS, Inc., Pleasanton, Calif.). Malic acid concentration was determined by injecting a $20-\mu \mathrm{L}$ aliquot of the extract into a high-performance liquid chromatography (HPLC) system, consisting of a HPLC pump (model 426; Waters, Milford, Mass.) and an amino column (Allsphere; Alltech Associates, Inc., Deerfield, Ill.), an injection loop (Rheodyne, L.P., Cotati, Calif.), and a variable wavelength photometric absorbance detector ( $\mathrm{V}^{4}$; ISCO, Inc., Lincoln, Nebr.), set at $205 \mathrm{~nm}$. Several concentrations of pure L-malic acid (Sigma, St. Louis) were used as standards.

Fig. 1. Irradiance at solar noon under three levels of GH shade (Weslaco, Texas; latitude $26.15^{\circ} \mathrm{N}$ ) from July 1996 to August 1997.

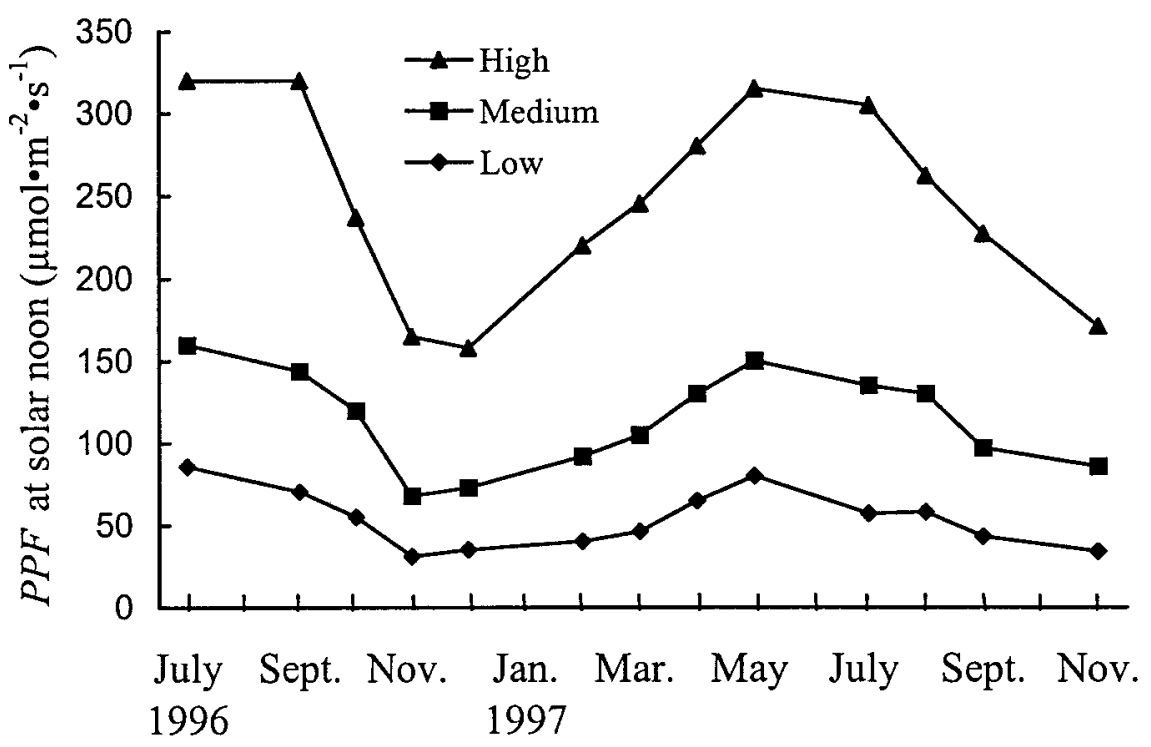


Table 1. Effects of four in vitro PPF levels on growth of a hybrid Phalaenopsis Atien Kaala seedling.

\begin{tabular}{|c|c|c|c|c|c|c|c|}
\hline \multirow[b]{2}{*}{$\begin{array}{l}\text { In vitro } P P F \\
\left(\mu \mathrm{mol} \cdot \mathrm{m}^{-2} \cdot \mathrm{s}^{-1}\right)\end{array}$} & \multicolumn{4}{|c|}{ Leaf } & \multicolumn{2}{|c|}{ Root } & \multirow{2}{*}{$\begin{array}{c}\text { Total } \\
\text { Fresh } \\
\text { wt } \\
\text { (g) }\end{array}$} \\
\hline & No. & $\begin{array}{l}\text { Width } \\
\text { (cm) }\end{array}$ & $\begin{array}{l}\text { Length } \\
(\mathrm{cm})\end{array}$ & $\begin{array}{l}\text { Ratio } \\
(\mathrm{W}: \mathrm{L})\end{array}$ & No. & $\begin{array}{c}\text { Length } \\
(\mathrm{cm})\end{array}$ & \\
\hline 10 & $3.13 b^{z}$ & $1.38 \mathrm{c}$ & $4.14 \mathrm{a}$ & $0.35 \mathrm{c}$ & $4.98 \mathrm{~b}$ & $2.84 \mathrm{~b}$ & $0.68 \mathrm{~b}$ \\
\hline 20 & $3.30 \mathrm{ab}$ & $1.50 \mathrm{bc}$ & $4.07 \mathrm{a}$ & $0.38 \mathrm{c}$ & $5.34 \mathrm{~b}$ & $2.83 \mathrm{~b}$ & $0.74 \mathrm{~b}$ \\
\hline 40 & $3.41 \mathrm{a}$ & $1.66 \mathrm{a}$ & $3.84 \mathrm{a}$ & $0.44 \mathrm{~b}$ & $6.57 \mathrm{a}$ & $3.95 \mathrm{a}$ & $0.96 \mathrm{a}$ \\
\hline 80 & $3.06 \mathrm{c}$ & $1.54 \mathrm{ab}$ & $3.15 \mathrm{~b}$ & $0.50 \mathrm{a}$ & $6.85 \mathrm{a}$ & $4.08 \mathrm{a}$ & $0.96 \mathrm{a}$ \\
\hline
\end{tabular}

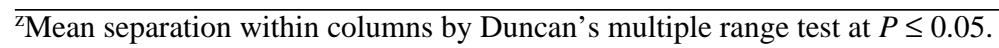

Carbohydrate analysis. Glucose, fructose, and sucrose concentrations in leaves were determined using the procedures of Hendrix (1993) with some modification. Tissue samples were collected between 1600 and 1700 HR from the second youngest mature leaf. Leaf discs were collected with a $1.04-\mathrm{cm}$-i.d. borer, in four preselected areas of the leaf, two from each side of the center vein, avoiding the leaf margins. Tissues were immersed immediately in a test tube containing $2 \mathrm{~mL}$ of $0{ }^{\circ} \mathrm{C} 80 \%$ ethanol. Six washes at $80^{\circ} \mathrm{C}$, for 15 min each with $2 \mathrm{~mL}$ of $80 \%$ ethanol, were necessary to remove all soluble sugars. The ethanol sugar extracts were combined, clarified by addition of fine activated charcoal powder, centrifuged at $10000 g_{\mathrm{n}}$ for $10 \mathrm{~min}$, filtered, and brought to $20 \mathrm{~mL}$. A $40 \mu \mathrm{L}$ aliquot of each sample was dried in a microtitration plate at $50^{\circ} \mathrm{C}$ to remove ethanol and water and then redissolved in $20 \mu \mathrm{L}$ of deionized water. Iodonitrotetrazolium violet (INT) solution was added $(150 \mu \mathrm{L})$ and incubated for 20 min at $37{ }^{\circ} \mathrm{C}$ to allow for complete reaction with any glucose present. Glucose was then determined by colorimetric analysis using an ELISA plate reader (Titertek Uniskan II; Flow Labora- tories, McLean, Va.) set at $492 \mathrm{~nm}$. A $10 \mu \mathrm{L}$ solution of phosphoglucosisomerase (PGI) was added to each well in the previously read plate and incubated for $15 \mathrm{~min}$ at $37^{\circ} \mathrm{C}$ to convert fructose to glucose. The sample plate was again read to determine the sum of glucose and fructose (hexoses). Sucrose was determined by adding $10 \mu \mathrm{L}$ of invertase immediately after determination of hexoses, incubated at $37^{\circ} \mathrm{C}$ for 15 min., and absorbency read at $492 \mathrm{~nm}$.

Samples for starch analysis were collected by using the portion of leaf remaining after removing samples for sugar analysis. A leaf was collected and immersed immediately in boiling water for $15 \mathrm{~s}$ to kill the tissue. The leaf was then placed in a forced air drying oven at $70^{\circ} \mathrm{C}$ for $4 \mathrm{~d}$. The dried leaves were ground in a Wiley mill to pass a 60 -mesh $(0.423-\mathrm{mm})$ screen and stored until analysis could be performed a few days later. A $25 \mathrm{mg}$ dry sample of the ground tissue was used. Soluble sugars were extracted with $80 \%$ (v/v) ethanol (Tetley, 1974). Hot, $\approx 80{ }^{\circ} \mathrm{C}, 80 \%$ ethanol was added $(2 \mathrm{~mL})$ and centrifuged for $10 \mathrm{~min}$ at $10,000 \mathrm{~g}_{\mathrm{n}}$ and decanted. Extraction was repeated six times, vortexing between

Table 2. Effects of in vitro and greenhouse $P P F$ on fresh weight of Phalaenopsis Atien Kaala seedling plants at various stages.

\begin{tabular}{|c|c|c|c|c|c|}
\hline \multirow{4}{*}{$\begin{array}{l}\text { In vitro } P P F \\
\left(\mu \mathrm{mol} \cdot \mathrm{m}^{-2} \cdot \mathrm{s}^{-1}\right)\end{array}$} & \multicolumn{5}{|c|}{ Fresh wt (g) } \\
\hline & \multicolumn{2}{|c|}{ Total plant } & & & \\
\hline & \multirow{2}{*}{$\begin{array}{c}29 \text { Nov. } \\
1996\end{array}$} & \multirow{2}{*}{$\begin{array}{c}28 \text { June } \\
1997\end{array}$} & \multicolumn{3}{|c|}{ September 1997} \\
\hline & & & Shoot & Root & Total \\
\hline \multicolumn{6}{|l|}{ High GH $P P F^{Z}$} \\
\hline 10 & $10.2 b^{y}$ & $48.0 \mathrm{~b}$ & $76.6 \mathrm{a}$ & $39.7 \mathrm{a}$ & $116 \mathrm{a}$ \\
\hline 20 & $13.0 \mathrm{ab}$ & $59.7 \mathrm{ab}$ & $83.0 \mathrm{a}$ & $42.3 \mathrm{a}$ & $125 \mathrm{a}$ \\
\hline 40 & $15.3 \mathrm{a}$ & $73.0 \mathrm{a}$ & $84.8 \mathrm{a}$ & $43.8 \mathrm{a}$ & $129 \mathrm{a}$ \\
\hline 80 & $13.4 \mathrm{a}$ & $65.1 \mathrm{a}$ & $96.7 \mathrm{a}$ & $48.0 \mathrm{a}$ & $145 \mathrm{a}$ \\
\hline \multicolumn{6}{|l|}{ Medium GH $P P F^{\mathrm{z}}$} \\
\hline 10 & $9.3 \mathrm{~b}$ & $31.5 \mathrm{~b}$ & $39.8 \mathrm{a}$ & $19.9 \mathrm{a}$ & $60 \mathrm{ab}$ \\
\hline 20 & $9.6 \mathrm{~b}$ & $36.2 \mathrm{ab}$ & $38.3 \mathrm{a}$ & $19.0 \mathrm{a}$ & $57 \mathrm{~b}$ \\
\hline 40 & $11.8 \mathrm{a}$ & $42.0 \mathrm{a}$ & $47.0 \mathrm{a}$ & $23.3 \mathrm{a}$ & $70 \mathrm{a}$ \\
\hline 80 & $11.6 \mathrm{a}$ & $36.2 \mathrm{ab}$ & $39.8 \mathrm{a}$ & $19.4 \mathrm{a}$ & $59 \mathrm{ab}$ \\
\hline \multicolumn{6}{|l|}{ Low GH $P P F^{\mathrm{z}}$} \\
\hline 10 & $5.3 \mathrm{~b}$ & $15.0 \mathrm{a}$ & $18.9 \mathrm{a}$ & $5.0 \mathrm{~b}$ & $24 \mathrm{~b}$ \\
\hline 20 & $5.9 \mathrm{ab}$ & $16.0 \mathrm{a}$ & $20.8 \mathrm{a}$ & $5.6 \mathrm{~b}$ & $26 \mathrm{ab}$ \\
\hline 40 & $6.8 \mathrm{a}$ & $18.4 \mathrm{a}$ & $20.1 \mathrm{a}$ & $6.1 \mathrm{~b}$ & $27 \mathrm{ab}$ \\
\hline 80 & $6.9 \mathrm{a}$ & $19.5 \mathrm{a}$ & $24.6 \mathrm{a}$ & $7.4 \mathrm{a}$ & $32 \mathrm{a}$ \\
\hline \multicolumn{6}{|l|}{ Significance } \\
\hline In vitro & $* * *$ & $* * *$ & NS & NS & NS \\
\hline $\mathrm{GH} P P F$ & $* * *$ & $* * *$ & $* * *$ & $* * *$ & $* * *$ \\
\hline In vitro $\times \mathrm{GH} P P F$ & NS & NS & NS & NS & NS \\
\hline
\end{tabular}

${ }^{\mathrm{z}}$ Overall means for high, medium, and low GH $P P F$ were $12 \%, 5.4 \%$, and $2.6 \%$ of full sunlight, respectively.

y Mean separation within columns and GH $P P F$ by Duncan's multiple range test at $P \leq 0.05$.

Ns,***N Nonsignificant or significant at $P \leq 0.001$, respectively. 
Table 3. Effects of three levels of GH PPF on leaf characteristic of the youngest mature leaf (after $422 \mathrm{~d}$ ) and on leaf number and total leaf area of Phalaenopsis Atien Kaala seedlings (after $443 \mathrm{~d})^{\mathrm{z}}$

\begin{tabular}{|c|c|c|c|c|c|}
\hline \multirow[b]{2}{*}{ GH $P P F$} & \multicolumn{3}{|c|}{ Youngest mature leaf } & \multirow[b]{2}{*}{$\begin{array}{l}\text { Total } \\
\text { leaves }\end{array}$} & \multirow{2}{*}{$\begin{array}{c}\text { Leaf } \\
\text { area } \\
\left(\mathrm{cm}^{2} / \text { plant }\right)\end{array}$} \\
\hline & $\begin{array}{l}\text { Length } \\
(\mathrm{cm})\end{array}$ & $\begin{array}{l}\text { Width } \\
(\mathrm{cm})\end{array}$ & $\begin{array}{c}\text { Thickness } \\
(\mathrm{mm})\end{array}$ & & \\
\hline$\overline{\text { High }}$ & $18.9 \mathrm{a}^{\mathrm{z}}$ & $5.9 \mathrm{a}$ & $2.3 \mathrm{a}$ & $6.4 \mathrm{a}$ & $419 a$ \\
\hline Medium & $14.8 \mathrm{~b}$ & $5.1 \mathrm{~b}$ & $1.8 \mathrm{~b}$ & $5.7 \mathrm{~b}$ & $258 \mathrm{~b}$ \\
\hline Low & $12.8 \mathrm{c}$ & $4.3 \mathrm{c}$ & $1.3 \mathrm{c}$ & $4.9 \mathrm{c}$ & $163 \mathrm{c}$ \\
\hline \multicolumn{6}{|l|}{ Significance } \\
\hline $\mathrm{GH} P P F$ & $* * *$ & $* * *$ & $* * *$ & $* * *$ & $* * *$ \\
\hline In vitro $\times \mathrm{GH} P P F$ & NS & NS & NS & $*$ & NS \\
\hline
\end{tabular}

${ }^{\mathrm{z}}$ Mean separation within columns by Duncan's multiple range test at $P \leq 0.05$.

ss, $* * * * *$ Nonsignificant or significant at $P \leq 0.05$ or 0.001 , respectively.

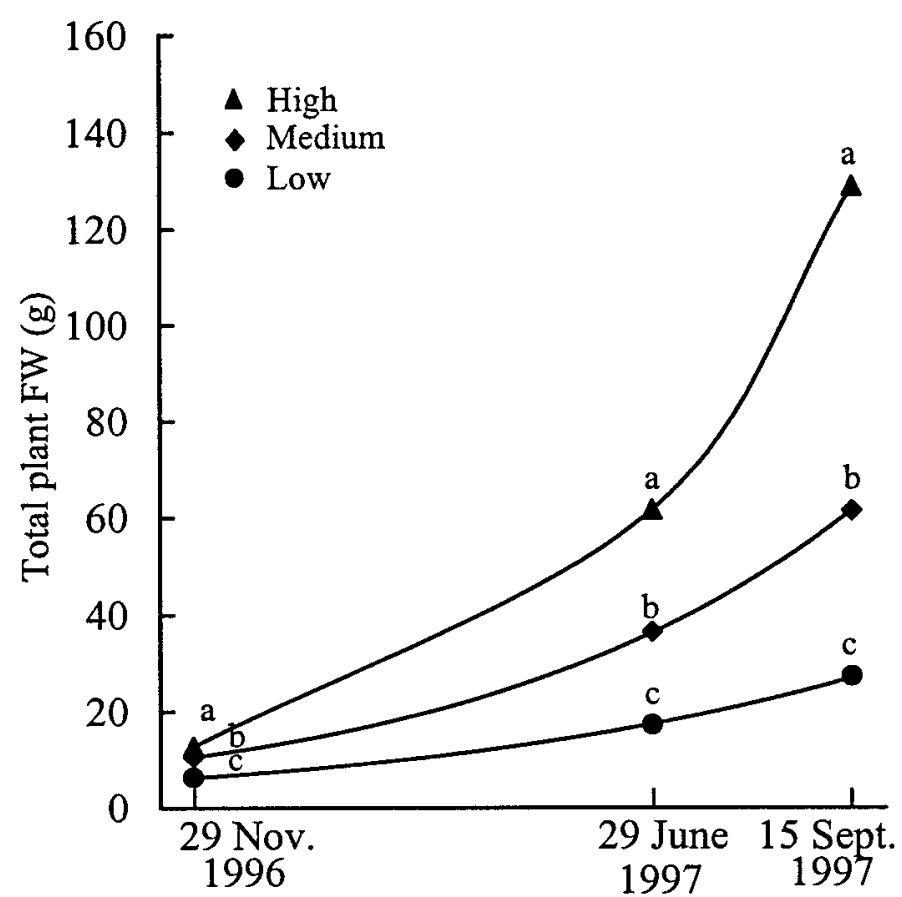

Fig. 2. Effects of greenhouse PPF on mean total FW of Phalaenopsis Atien Kaala seedlings at several stages throughout the experiment. Mean separation within dates by Duncan's multiple range test, $P \leq 0.05$ ( $\mathrm{n}=24$ for November 1996 and June 1997; $n=11$ for September 1997).

each extraction. After extraction was completed, procedures for enzymatic starch digestion and colorimetric carbohydrate determination, as described by Hendrix (1993), were used to determine the glucose concentration in the samples and starch concentration was then calculated.

Flowering Data. Dates of first flower opening (anthesis) were recorded when the flowers had opened flat on plants in the remaining replications. Once a total of three flowers had opened on an inflorescence, the diameter across the face of the lateral petals on the most mature flower was measured. The total number of flowers on each plant was recorded. Within each GH PPF, the set of four plants from the four in vitro $P P F$ in each replication were used for determination of percentage flowering.

Throughout the experiment, plants were fertigated as needed with reverse osmosis water (electrical conductivity $=0.03 \mathrm{dS} \cdot \mathrm{m}^{-1}$ ) containing $1.0 \mathrm{~g} \cdot \mathrm{L}^{-1}$ of a soluble, $20 \mathrm{~N}-8.6 \mathrm{P}-16.6 \mathrm{~K}$ fertilizer (ScottsSierra Hort. Products, Marysville, Ohio). The fungicide 5-ethoxy3-trichloromethyl-1, 2,4-thiaiazole [Truban (Sierra Crop Protection Co., Milpitas, Calif.)] at $225 \mathrm{mg} \cdot \mathrm{L}^{-1}$ was used as a soil drench every time plants were transplanted. Data were analyzed as a split plot, with GH PPF being the main plots and the in vitro $P P F$ being the subplots. SAS programming (SAS Inst., Inc., Cary, N.C.) was used for statistical analysis. Regression analysis was used to determine trends and means separated by Duncan's multiple range test. Percentages flowering data were arcsine transformed before analysis.

\section{Results}

IN VITRO PHASE. The $40 \mu \mathrm{mol} \cdot \mathrm{m}^{-2} \cdot \mathrm{s}^{-1}$ in vitro $P P F$ treatment resulted in plantlets with the highest leaf number, while plants under 10 or $80 \mu \mathrm{mol} \cdot \mathrm{m}^{-2} \cdot \mathrm{s}^{-1} P P F$ had the lowest leaf numbers (Table 1 ). As in vitro $P P F$ increased, leaf width increased, but length decreased, resulting in increased width to length ratio (from 0.35 to 0.50 ) and rounder leaves. Root length and root number at the time of transplanting from in vitro to seedling trays were $10 \%$ greater in the 40 and $80 \mu \mathrm{mol} \cdot \mathrm{m}^{-2} \cdot \mathrm{s}^{-1} P P F$ than those under the two lower $P P F$. Plants under the two higher in vitro $P P F$ had $38 \%$ greater $F W$ s than those under the two lower in vitro $P P F$.

Greenhouse Phase. During the earlier stages (November 1996 and June 1997), under the high or medium GH PPF, plants produced previously under the $40 \mu \mathrm{mol} \cdot \mathrm{m}^{-2} \cdot \mathrm{s}^{-1}$ in vitro $P P F$ had greater FWs than those under the $10 \mu \mathrm{mol} \cdot \mathrm{m}^{-2} \cdot \mathrm{s}^{-1} P P F$ in vitro

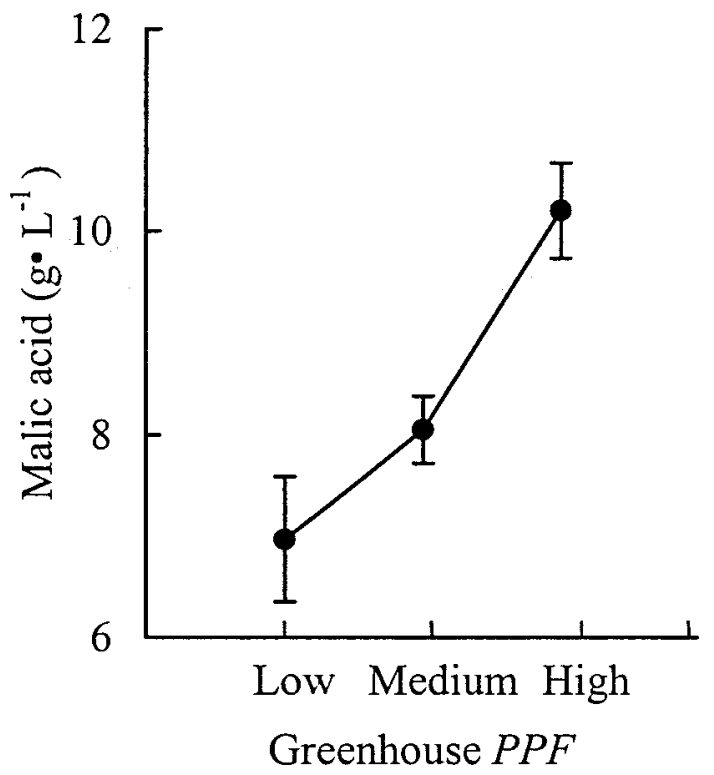

Fig. 3. Malic acid concentration in leaves of Phalaenopsis Phalaenopsis Atien Kaala seedlings under three GH irradiance levels. Verticle bars \pm SE $(n=3)$. 


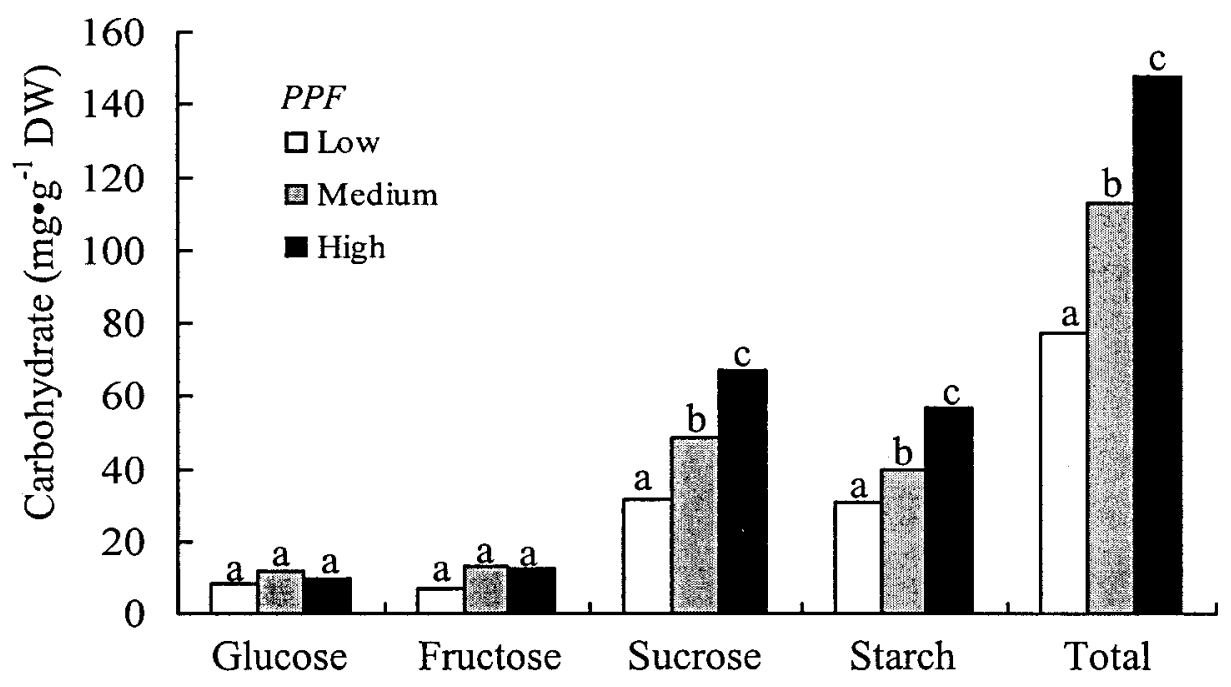

Sept. 1997), FW of plants under the high GH $P P F$ doubled, but those under the medium and low GH $P P F$ increased only by $60 \%$. These patterns reflect a vast growth advantage for plants exposed to the high GH $P P F$.

MALIC ACID AND CAROBHYDRATE CONCENTRATIONS. Malic acid concentration in leaf tissues increased as GH $P P F$ increased (Fig. 3). Concentrations of glucose and fructose were similar, regardless of GH PPF. Differences in mean concentrations of sucrose and starch in leaves were highly significant among the three GH PPF levels (Fig. 4). As irradiance increased, mean sucrose concentration increased. A similar increase in starch concentration resulted in increasingly higher total car-

Fig. 4. Carbohydrate levels in leaves of Phalaenopsis Atien Kaala seedlings grown under one of three GH PPF levels. Mean separation within categories by Duncan's multiple range test, $P \leq 0.05(\mathrm{n}=3)$.

(Table 2). However, under the low GH PPF, the larger plants previously under 40 or $80 \mu \mathrm{mol} \cdot \mathrm{m}^{-2} \cdot \mathrm{s}^{-1}$ in vitro $P P F$ did not gain any growth advantage from their larger initial size due to the limited growth of all plants.

By 15 Sept. 1997 (79 d after the previous evaluation and 443 d since seedlings were transferred to the greenhouse), all plants within each of the high or medium GH PPF had similar FWs, regardless of their in vitro $P P F$ origin (Table 2 ). However, under the low GH $P P F$, plants that were produced in vitro under the 80 $\mu \mathrm{mol} \cdot \mathrm{m}^{-2} \cdot \mathrm{s}^{-1} P P F$ had $33 \%$ greater $\mathrm{FW}$ than those under 10 $\mu \mathrm{mol} \cdot \mathrm{m}^{-2} \cdot \mathrm{s}^{-1} P P F$ (Table 2). As time and irradiance increased in the greenhouse, there was a corresponding increase in whole plant FW.

In mid-September 1997, increased GH $P P F$ resulted in plants with longer, wider, and thicker leaves, greater leaf number, and larger total leaf area (Table 3). Each increment of GH PPF resulted in more than doubling plant FW (Fig. 2). Overall, as GH $P P F$ increased, the increase in whole plant $\mathrm{FW}$ over time appeared to shift from a linear to an exponential pattern. Between November 1996 and June 1997, plants under the high, medium, or low GH PPF had average FW gains of 230, 123, and $52 \mathrm{mg} \cdot \mathrm{d}^{-1}$, respectively (Fig. 2 ). These values increased to 852,317 , and $126 \mathrm{mg} \cdot \mathrm{d}^{-1}$ during the next $79 \mathrm{~d}$.

The FWs of plants grown in the high GH PPF increased nearly $400 \%$ from November to June (Fig. 2), whereas, during this same period, plants under the medium or low GH PPF had $250 \%$ and $180 \%$ increase in FW, respectively. During the next $79 \mathrm{~d}$ (by 15 bohydrate levels as $P P F$ increased from low to high (Fig. 4)

Flowering. High GH $P P F$ resulted in earlier flowering than the medium or low PPF (Table 4). Anthesis occurred 2 weeks earlier under the high GH PPF. The difference in the number of plants that reached flowering was highly significant among the treatments. Nearly all of the plants under the high PPF treatment produced flowers $(98 \%)$ (Table 4). In contrast, few of the plants under low treatment produced flowers $(2 \%)$. Due to the extremely low flower initiation under the low GH $P P F$, no other flowering data could be evaluated in this treatment. Plants grown under the high GH PPF produced more inflorescences, twice as many flowers, and larger flowers than those under the medium PPF (Table 4).

\section{Discussion}

Results of this study demonstrated that low initial growth rates of Phalaenopsis seedlings ex vitro may be improved if adequate $P P F$ levels are provided to stimulate growth during the in vitro period. In vitro $P P F$ of $40 \mu \mathrm{mol} \cdot \mathrm{m}^{-2} \cdot \mathrm{s}^{-1}$ or $80 \mu \mathrm{mol} \cdot \mathrm{m}^{-2} \cdot \mathrm{s}^{-1}$ produced Phalaenopsis seedlings with better root growth and greater FW, which may be transferred out of flasks at an earlier time. Also, increased leaf number in plantlets grown at 40 $\mu \mathrm{mol} \cdot \mathrm{m}^{-2} \cdot \mathrm{s}^{-1}$ may indicate stimulation of photosynthesis in vitro. Navarro et al. (1994) noted that higher dry matter in banana (Musa sapientum Kuntze) plantlets in vitro and later ex vitro was found in plants grown under high irradiance in vitro. In this study, when Phalaenopsis orchid seedlings were grown under $40 \mu \mathrm{mol} \cdot \mathrm{m}^{-2} \cdot \mathrm{s}^{-1}$ in vitro $P P F$, they were of overall superior quality than plants grown under the other $P P F$ levels. Although differences in leaf numbers were small, biologically, higher leaf numbers resulted in larger

Table 4. Effects of three GH PPF levels on flowering of Phalaenopsis Atien Kaala seedlings.

\begin{tabular}{|c|c|c|c|c|c|}
\hline GH $P P F$ & $\begin{array}{c}\text { Plants } \\
\text { bloomed } \\
(\%)\end{array}$ & $\begin{array}{l}\text { No. } \\
\text { spikes }\end{array}$ & $\begin{array}{c}\text { Anthesis } \\
\text { date }\end{array}$ & $\begin{array}{c}\text { Total } \\
\text { flowers/plant }\end{array}$ & $\begin{array}{c}\text { Flower } \\
\text { width } \\
(\mathrm{cm})\end{array}$ \\
\hline$\overline{\text { High }}$ & $98 \mathrm{a}^{\mathrm{z}}$ & $1.3 \mathrm{a}$ & 16 Jan. $98 \mathrm{a}$ & $8 \mathrm{a}$ & $10.9 \mathrm{a}$ \\
\hline Medium & $77 \mathrm{~b}$ & $1.1 \mathrm{~b}$ & 1 Feb. 98 b & $4 \mathrm{~b}$ & $10.4 \mathrm{~b}$ \\
\hline Low $^{y}$ & $2 \mathrm{c}$ & --- & --- & --- & --- \\
\hline Significance & $* * *$ & $* *$ & $* *$ & $* * *$ & $* *$ \\
\hline
\end{tabular}

${ }^{\mathrm{Z}}$ Mean separation within columns by Duncan's multiple range test, $P \leq 0.05$.

${ }^{y}$ Missing data were due to insufficient values for statistical analysis.

**,*** Significant at $P \leq 0.01$ or 0.001 , respectively. 
total leaf area because leaf size increases in successive younger leaves. Increased growth rates and leaf size would allow for earlier transplanting to the greenhouse, with subsequent reduction in production time and cost.

Mean malic acid concentration was greatest in leaves of Phalaenopsis plants grown under the high PPF. Skillman and Winter (1997) found that, when given saturating light, high levels of malate found in some shade tolerant CAM plants allow for increased photosynthesis for a longer period of the day. This may increase the growth rate of plants under high irradiance as evidenced by the greater FW of Phalaenopsis plants grown under the higher $P P F$. The additive effect of higher energy captured during the day and larger overall leaf area allowed plants to produce larger quantities of malic acid and thus promoted further increases in photosynthesis and much rapid growth. Although leaf photosynthetic rate was not determined in this study, the increased FW of plants grown under higher $P P F$ is most likely a net result of increased photosynthesis. It would be expected that higher total carbohydrate concentrations would be found in plants with higher than lower photosynthetic rates.

Changes in starch, sucrose, and glucose concentration in the leaves frequently coincide with mobilization of carbohydrates necessary for flower spike formation. In a study by Lee and Lee (1991), starch and glucose levels decreased, while sucrose level rose in leaves of a hybrid Phalaenopsis after plants had been exposed to low temperatures and immediately before flower stalk emergence. While the present study did not examine carbohydrate levels at different stages, sucrose level was generally higher than glucose, fructose, or starch. Glucose and fructose levels remained at a 1:1 ratio regardless of $\mathrm{GH} P P F$ levels. This suggests that the hexoses above the observed levels may be actively converted to sucrose and starch. Those plants receiving low $\mathrm{GH}$ $P P F$, although glucose and fructose levels did not differ, had half the total carbohydrate levels as plants receiving the high GH PPF. Plants which received the medium GH PPF had two-thirds the total carbohydrates levels and flowered $\approx 2$ weeks after those in the high GH PPF. The increase in time to flower may have been necessary for production or conversion of carbohydrate needed for flower spike initiation and development. Lee and Lee (1991) reported previously that sucrose level may play an important role in flower stalk emergence.

Higher levels of greenhouse PPF such as those used in the present investigation would result in larger plants, earlier flowering, with more and larger flowers possibly due to increased photosynthesis leading to higher carbohydrates concentrations and increased growth rates. Further studies could lead to better control of flowering date by manipulating light levels in combi- nation with temperature and, possibly, using carbohydrate concentrations in leaves to predict the ability of plants to flower.

\section{Literature Cited}

Economou, A.S. and P.E. Read. 1987. Light treatments to improve efficiency of in vitro propagation systems. HortScience 22:751-754.

Fanfani, A. and W. Rossi. 1988. Simon \& Schuster's guide to orchids. Fireside book, Simon \& Schuster, New York.

Griesbach, R. 1995. A Phalaenopsis in every pot. Orchid Dig. 59(1):4243.

Hendrix, D.L. 1993. Rapid extraction and analysis of nonstructural carbohydrates in plant tissues. Crop Sci. 33:1306-1311.

Hew, C.S. and J.W.H. Yong. 1997. The physiology of tropical orchids in relation to the industry. World Scientific Publ. Co. Pte. Ltd., River Edge, N.J.

Kajihara, S. 1993. Effects of temperature and daylength on the growth and flowering of Phalaenopsis. Hiroshima Perfectural Agr. Res. Ctr. 93-O-Hirsohima, Japan.

Kubota, S., T. Hisamitsu, and M. Koshioka. 1997. Estimation of malic acid metabolism by measuring $\mathrm{pH}$ of hot water extracts of Phalaenopsis leaves. Scientia Hort. 71:251-255.

Lee, N. 1990. Forcing culture of Phalaenopsis in Taiwan, p. 169-178. In: Off-season production of horticultural crops. Food and Fertilizer Tech. Ctr. Book Ser. No. 41

Lee, C.H. and N. Lee. 1991. Characteristics of morphology and anatomy in root and leaf of Phalaenopsis amabilis. J. Chinese Soc. Hort. Sci. 37:237-248

Navarro, C., C. Teisson, F. Cote, and J. Ganry. 1994. Effects of light intensity and $\mathrm{CO}_{2}$ concentration on growth of banana plants (Musa AAA, Cultivar 'Petite Naine') in vitro and subsequent growth following acclimatization. Scientia Hort. 60:41-54.

Skillman, J.B. and K. Winter. 1997 High photosynthetic capacity in a shade-tolerant crassulacean acid metabolism plant. Plant Physiol. 113:441-450.

Tetley, R.M. 1974. Studies on hormonal control of growth and metabolism in cultured tobacco pith explants. PhD diss. Univ. of Michigan, Ann Arbor.

Ueda, H. and H. Torikata. 1972. Effects of light and culture medium on adventitious root formation of Cymbidiums in aseptic culture. Amer. Orchid Soc. Bul. 41:323-327.

U.S. Department of Agriculture. 1997. Floriculture crops summary 1996. U.S. Dept. Agr., Wash., D.C.

U.S. Department of Agriculture. 2000. Floriculture crops summary 1999. U.S. Dept. Agr., Wash., D.C.

Wang, Y.T. 1995. Phalaenopsis orchid light requirement during the induction of spiking. HortScience 30:59-61.

Wang, Y.T. 1997. Phalaenopsis light requirements and scheduling of flowering. Orchids 66:934-939.

Wang, Y.T. 1998. Deferring flowering of greenhouse-grown Phalaenopsis orchids by alternating dark and light. J. Amer. Soc. Hort. Sci. 123:56-60. 